\title{
Interesting viewpoints on Laestadianism in Finland
}

Politiikka, talous ja työ. Lestadiolaisuus maailmassa, eds. Aini Linjakumpu, Tapio Nykänen, Tiina Harjumaa and Sandra Wallenius-Korkalo (Rovaniemi, Lapland University Press, 2019), 291 pp.

In recent years, research on Conservative Laestadianism has become quite visible and multifold in Finland. This research interest has increased together with lively discussions in the mass media and the emergence of various artistic representations. In the Finnish sphere, there is a truly huge boom of different topics and stories related to Conservative Laestadianism. This interest is especially significant when a growing secularization and religious disaffiliation within the Finnish common space is kept in mind.

When it comes to the research field, it is important to notice how different scholarly presentations of Conservative Laestadianism are not solely limited to the field of religious scholarship (theology, comparative religion), but also other research disciplines have been actively involved.

The anthology Politiikka, talous ja työ. Lestadiolaisuus maailmassa (Politics, economics and work: Laestadianism in the world) is a new contribution, which

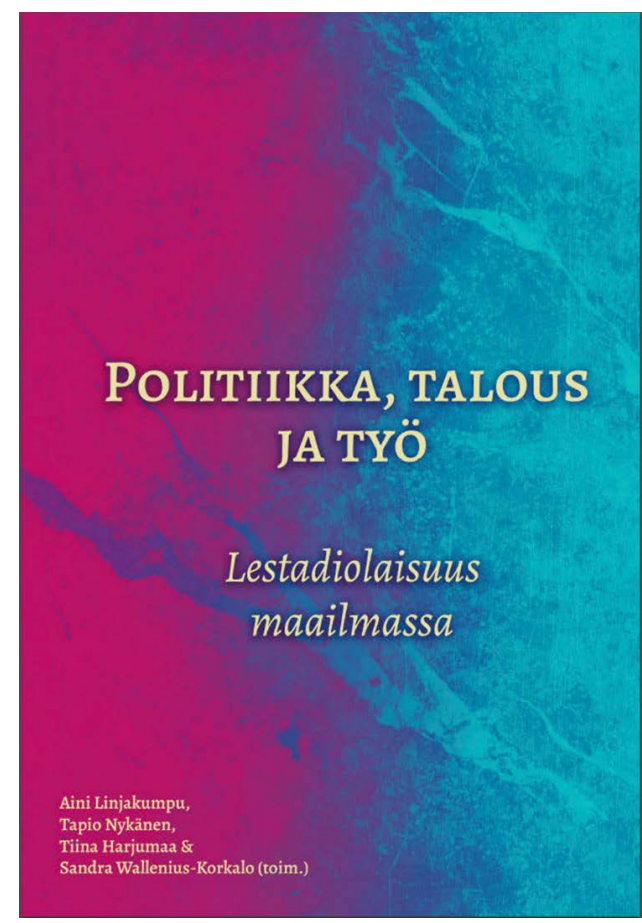

extends a new wave of Finnish scholarship charting different aspects of Laestadianism. Several Finnish scholars with expertise in Laestadianism have contributed their own articles to the book. In some cases, it maybe would have been interesting to find out more about the positions of the authors in relation to the movement (even though this also came up in at least one of the articles). This question, as an important issue in all research, has become actual 
for myself, but it is of course possible that my own background as a researcher has coloured my own understanding, which I necessarily do not share with other research traditions. Nevertheless, for me as a theologian it was very rewarding to read this anthology, which was concentrated on inspiration from research in the fields of history and the social sciences. In any case, questions of research ethics are reflected on and opened up in several articles, which can be seen as a means of increasing the credibility of the texts.

The overall aim for the book is to chart and analyse the relationships between Laestadianism and the world. The foreword reminds the reader of how religious communities are much more than merely religious communities; they also have many kinds of ties with the society around them. As the title already indicates, the theme of the book is answered by focusing on three bigger issues - politics, economics and work. The book consists of three main sections. In the first part Laestadianism is approached with politics as a starting point. The subsequent section is focused on the diverse economic aspects of two distinct Laestadian movements. The third and the last outlines issues related to work. The articles in these sections are focused on many different aspects within these three fields - cases from a local form of charity work motivated by Ostrobothnian Word of Peace Laestadianism (LFF) and the political impacts of different Laestadianisms on the production of the Sami artist and activist Nils-Aslak Valkeapää are analysed.

Different forms of Laestadianism most often Conservative Laestadianism, but in some cases, even other branches of the movement (LFF and Firstborn Laestadianism) - are analysed as powerful and relevant frameworks, which in many ways can be seen in relation to the surrounding society. I see this selection of many branches of Laestadianism as one of the most relevant points of the anthology. This approach can also be motivated by the common Finnish knowledge considering the different branches of the movement. The discussion around the Laestadian roots of the former Finnish Prime Minister Juha Sipilä, which is analysed in one of the articles, is one concrete example of this. It seems that many Finns have strong opinions about Laestadianism, but in many cases, a more nuanced understanding is missing. Therefore this kind of research definitely has its place.

Methodologically speaking, the articles in the anthology are written in a variety of ways. The range of different readings and approaches used in analysis do provide a rich flora of explorations, and diverse theories are also present. This richness can be seen in connection with the wealth of the materials used. Many different kinds of texts - from blogs and various kinds of media texts (both religious and secular) to poetry, business communication and official statements - are visible as sources. In some cases, the textual approaches are enriched with interviews, art analysis and even with the deployment of ethnographical methods. The richness of these different approaches does justice to the multiple realities and questions which are being analysed in the book.

The anthology shows how religion is a phenomenon which currently is far from being insignificant. Strong and even conservative religious groups have influence within the religious sphere, but also within other spheres, which in many cases work as shared arenas with non-believers and different values. The anthology reminds us of the other side of the coin in the Finnish situation, where different processes of secularization are present in a visible way. The 
anthology reminds the reader of how religion and different kinds of practices and manifestations connected with it are existing in many forms in Finnish society.

The examples presented in the anthology tell the story of how religion manifests itself as a collection of deep-rooted meanings, values and principles, which in various situations can be implemented on personal level. As a theologian, I have in mind how these kinds of concrete cases, which can be seen as encounters between different personal solutions, concrete societal and cultural situations and the collective tradition, could easily be seen from the perspective of lived religion. In other words, even theology and religious studies could be useful in these kinds of examinations which are rooted in concrete cases. However, the viewpoints and fields of study presented in the book are fruitful and convincing: religion and its different practical and lived forms of expression can be studied with the help of various perspectives. A certain balance and maybe even a cooperation between different approaches and research traditions would certainly be useful in future researches.

The eye of the anthology is mostly focused on the present and in some cases towards the past. This raises questions about the future. The future will show how different kinds of new challenges and societal and cultural processes may be integrated with the Laestadian tradition, which has been known for its Pietistic Lutheran moral ideals and strong collective practices. This is of course a constant challenge for all religious groups - what and how to preserve, what and how to reform? In the Finnish context, Laestadianism forms an interesting example of this.

This diverse and convincing collection of well-written texts can open some windows to these processes by showing how in many cases conservative religious convictions and the outside world can interact in ways which are at the same time contextual, but also have strong roots in the tradition. The book is a topical contribution to research on Laestadianism, but it surely can also contribute to other fields of research, especially those related to different kinds of religious studies. In addition, people outside the research sphere, but with an interest in Laestadianism, or even more generally in different manifestations of religion in (contemporary) society can surely see this collection of texts as a useful one.

Eetu Kejonen

Eetu Kejonen (Dr.Theol. 2014, Åbo Akademi University) is a librarian and a free researcher whose research interests include Finnish revivalist movements especially in the light of the LGBT issues. 